Jurnal Kesehatan Islam

e-ISSN : 2615-8345

Publikasi oleh Fakultas Kedokteran, Universitas Islam Malang

Pages: $1-10$

Email: jkesislam@unisma.ac.id

Home Page : http://riset.unisma.ac.id/index.php/jki

\title{
EFEKTIFITAS PEMBERIAN E-BOOKLET TENTANG PERMASALAHAN MENYUSUI TERHADAP PENINGKATAN PENGETAHUAN DOKTER UMUM DI PUSKESMAS KOTA MALANG
}

\author{
Ahmad Syauqie Al Muhdar*, Dewi Martha Indria**,Farida Rusnianah** \\ * Mahasiswa Program Studi Pendidikan Dokter, Fakultas Kedokteran Universitas Islam Malang \\ **Staf Pengajar Program Studi Pendidikan Dokter, Fakultas Kedokteran Universitas Islam \\ Malang \\ E-mail : yekalmuhdar@gmail.com, dewimarthaindria@unisma.ac.id, \\ farida.rusnianah@unisma.ac.id
}

\begin{abstract}
ABSTRAK
Pendahuluan : Permasalahan menyusui yang diakibatkan oleh permasalahan pada payudara merupakan salah satu faktor hilangnya minat ibu untuk menyusui. Sepertiga wanita yang berusia 25 tahun tidak menyusui karena pembengkakan payudara. Selain itu, puting terbenam,puting datar, puting lecet, saluran susu tersumbat, mastitis, dan abses payudara juga menyebabkan keengganan ibu untuk menyusui. Dokter umum di puskesmas sebagai dokter layanan primer sebaiknya memiliki pengetahuan yang baik tentang permasalahan menyusui. Pengetahuan yang baik akan membantu dokter umum untuk menyelesaikan kasus permasalahan menyusui. Salah satu cara untuk meningkatkan pengetahuan yaitu dengan menggunakan media pembelajaran. Dewasa ini, hampir setiap orang memiliki smartphone. Hal ini mendorong untuk menggunakan media pembelajaran berbasis elektronik berupa e-booklet. Penelitian ini bertujuan untuk mengetahui efektifitas pemberian e-booklet tentang permasalahan menyusui terhadap peningkatan pengetahuan dokter umum di puskesmas Kota Malang.

Metode : Jenis Penelitian ini adalah kuantitatif, menggunakan metode quasi experiment dengan desain penelitian one group pretest-posttest design dengan total sampling. Populasi diketahui sebesar 35 yaitu seluruh dokter umum bekerja di puskesmas Kota Malang dengan kriteria inklusi yaitu, dokter umum yang bersedia menjadi responden dan dokter umum fungsional yang bekerja di puskesmas Kota Malang. Sampel diperoleh yaitu sebanyak 23 orang. Kuesioner diberikan untuk mengukur pengetahuan sebelum dan setelah pemberian e-booklet. Data dianalisis dengan Uji $\mathrm{t}$ Berpasangan $(\mathrm{p}<0,05)$.

Hasil : Terdapat perbedaan rata-rata antara sebelum dan sesudah pemberian e-booklet. Diperoleh hasil $\mathrm{t}_{\text {hitung }}$ sebesar -12,500 dengan nilai signifikansi sebesar 0,000.

Kesimpulan : E-booklet efektif meningkatkan pengetahuan dokter umum terkait permasalahan menyusui

Kata Kunci : Pengetahuan, Dokter Umum, E-booklet, Permasalahan Menyusui, Puskesmas

The Effectiveness of E-booklet on Breastfeeding Problems to Increase the Knowledge of General Practitioner at Public Health Center of Malang City

Ahmad Syauqie Al Muhdar*, Dewi Martha Indria**, Farida Rusnianah**

Student of Medical Education, Faculty of Medicine, Islamic University of Malang

Lecturer in Medical Education Program, Faculty of Medicine, Islamic University of Malang e-mail :yekalmuhdar@gmail.com
\end{abstract}

\begin{abstract}
Background : Breastfeeding problems are caused by breast problems which are one of the factors that loss of the interest mothers to breastfeed. A third of women aged 25 years do not breastfeed because of breast swelling. In addition, inverted nipple, flat nipple, clogged duct, mastitis, and breast abscess are also cause mother's reluctance to breastfeed. General practitioner at Public
\end{abstract}


Health Center as primary care physicians should have a good knowledge how to troubleshoot breastfeeding problems. A good knowledge will help general practitioner to resolve the cases of confession. One way to increase to knowledge by using learning media. Today almost everyone has a smartphone. It is encouraged to use electronic based learning media in the form of $e$-booklet. This research aims to determine The Effectiveness of E-booklet on Breastfeeding Problems to Increase the Knowledge of General Practitioner at Public Health Center Malang City.

Methods : This type of research is the quantitative, using the quasi experiment method with the research design One Group Pretest-Posttest Design with total sampling. The population is known for 35 that is all the general practitioners working at Public Health Center with inclusion creteria, like general practitioners who are willing to be respondents and functional physicians who work in public health center of Malang city. Sample obtained as many as 23 people. Questionnaires were given to measure knowledge before and after the giving of e-booklet. Datas were analyzed by paired sample $\mathrm{t}$ test $(\mathrm{p}<0,05)$.

Results : There is an average difference between the value before and after the e-booklets. Average posttest value is higher than pretest.

Conclusion : E-booklet is effectively improve general practitioner's knowledge of breastfeeding problems.

Keywords : Knowledge, General Practitioner, E-booklet, Breastfeeding Problems, Public Health Center

\section{PENDAHULUAN}

Air Susu Ibu (ASI) adalah konsumsi terbaik untuk bayi dan anak-anak dan merupakan cara paling efektif untuk menjamin kesehatan dan kelangsungan hidup $^{1}$. Bayi dan anak-anak tidak hanya memperoleh kesehatan fisik tetapi dengan ASI mereka juga akan lebih cerdas secara emosional, spiritual serta perkembangan sosial yang lebih baik ${ }^{2}$.

Sepertiga wanita di dunia yang berusia lebih dari 25 tahun tidak menyusui dikarenakan mengalami pembengkakan payudara. Selain itu keengganan menyusui dapat disebabkan antara lain puting susu tenggalam, puting susu datar, puting susu lecet, saluran susu tersumbat, mastitis, atau bahkan abses payudara ${ }^{3}$.

Konsil Kedokteran Indonesia (KKI) sebagai regulator profesi kedokteran telah mengesahkan Standar Kompetensi Dokter Indonesia (SKDI). SKDI mencantumkan beberapa daftar masalah dan penyakit payudara. Hal ini berarti dokter dari lulusan setiap fakultas kedokteran di Indonesia di wajibkan untuk memiliki kemampuan mengatasi masalah dan penyakit payudara sesuai kompetensi yang tercantum ${ }^{4}$. Salah satu dokter yang wajib memiliki kemampuan tersebut yaitu dokter umum yang bekerja di Puskesmas.

Pusat Kesehatan Masyarakat (Puskesmas) yang merupakan pelaksana layanan kesehatan primer, seyogyanya harus memiliki dokter umum dengan kemampuan baik sesuai SKDI 2012 terutama terkait permasalahan menyusui. Hal tersebut dapat menunjang salah satu program yang telah dicanangkan menjadi program prioritas Dinas Kesehatan Provinsi Jawa Timur yaitu penurunan Angka Kematian Ibu dan Bayi ${ }^{5}$.

Dale mengemukakan manusia dapat menambah pengetahuan melalui alat indera yang dimilikinya, banyaknya alat indera yang digunakan dalam menerima informasi berbanding lurus dengan pengetahuan yang akan diperoleh. Pengetahuan yang diperoleh melalui indera penglihatan sebesar $75 \%$, melalui indera pendengaran sebesar $13 \%$, dan melalui indera lainnya sebesar $12 \%^{6}$.

Salah satu cara meningkatkan pengetahuan yaitu dengan media pembelajaran yaitu booklet. Booklet merupakan salah satu media edukasi yang memuat poin-poin penting berbentuk tulisan yang dikombinasikan dengan gambar yang menarik, sehingga dapat merangsang pembaca dalam meningkatkan pengetahuan ${ }^{7}$. Dewasa ini, hampir setiap orang memiliki smartphone dengan segala kelebihan yang dimiliki. Hal ini mendorong untuk memberikan media pembelajaran berbasis elektronik berupa $e$-booklet .

Penelitian ini bertujuan untuk mengetahui efektifitas pemberian e-booklet tentang permasalahan menyusui terhadap 
peningkatan pengetahuan dokter umum di puskesmas Kota Malang.

\section{METODE PENELITIAN}

Penelitian kuantitatif dengan metode quasi experiment menggunakan desain One Group Pretest-Posttest Design dilakukan di puskesmas Kota Malang, pada bulan Mei Juni 2017. Instrumen penelitian menggunakan kuesioner yang telah diuji validitas dan reliabilitas sebelumnya. Dilakukan uji validitas hingga semua nilai $\mathrm{r}_{\text {hitung }}>\mathrm{r}$ tabel . Sedangkan uji reliabilitas menggunakan rumus KR 21 didapatkan hasil 0,49075 yang berarti cukup valid. Sehingga kuesioner reliabel untuk digunakan. Untuk instrumen e-booklet juga dilakukan uji kevalidan yaitu kepada ahli media yang merupakan dosen Fakultas Sastra Universitas Negeri Malang dan ahli materi yaitu dokter umum yang merupakan konselor laktasi dengan gelar International Board Certified Lactation Consultant (IBCLC).

Penelitian ini telah disetujui oleh komisi etik penelitian kesehatan Fakultas Kedokteran Universitas Brawijaya (Ethical Clearance) nomor: 161 / EC / KEPK- S1- /04 I 2017.

Gambaran mengenai populasi, teknik pengambilan sampel, kriteria inklusi dan kriteria eksklusi, hingga jumlah sampel yang diperoleh terdapat pada Gambar 1. Setelah dilakukan teknik pengambilan sampel, sampel yang sesuai kriteria inklusi akan diikutsertakan dalam penelitian. Kemudian sampel yang termasuk kriteria eksklusi akan dikeluarkan dari penelitian. Dalam penelitian ini did|apatkan 23 sampel.

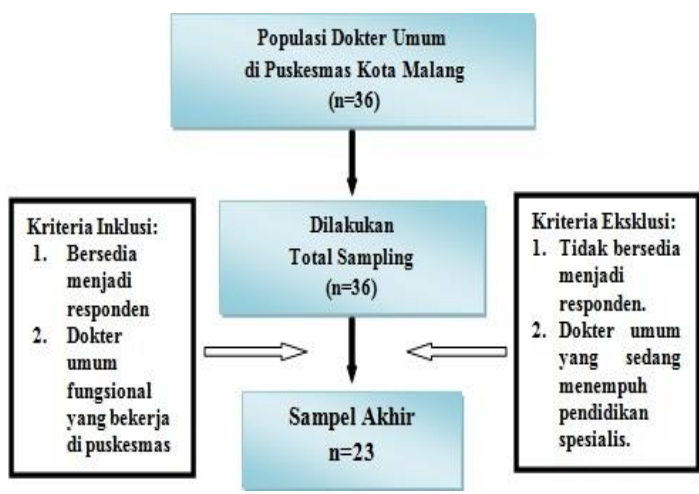

Gambar 1. Perolehan Sampel
Data terlebih dahulu diuji normalitas. Diperoleh hasil bahwa data pada penelitian ini berdistribusi normal. Oleh karena itu, uji hipotesis yang digunakan adalah metode parametrik yaitu Paired Sample $t$ Test. Metode ini untuk melihat perbedaan rata-rata hasil sebelum dan sesudah pemberian $e$ booklet. Dinyatakan efektif apabila $\left|\mathrm{t}_{\text {hitung }}\right|>$ $\mathrm{t}_{\text {tabel }}$ atau nilai signifikansi $<0,05$.

Variabel independen dalam penelitian ini adalah pemberian e-booklet. Untuk variabel dependen atau variabel terikat pada penelitian ini adalah pengetahuan dokter umum terkait permasalahan menyusui.

\section{HASIL DAN ANALISA DATA}

Pada penelitian ini karakteristik responden yang digambarkan berdasarkan jenis kelamin, usia, pengalaman menangani kasus permasalahan menyusui, pengalaman mengikuti pelatihan atau pendidikan laktasi, dan hambatan di tempat kerja dalam pelayanan terkait laktasi.

Tabel 1. Distribusi Responden Menurut Karakteristik Responden

\begin{tabular}{lr}
\hline $\begin{array}{l}\text { Karakteristik } \\
\text { Responden }\end{array}$ & $\mathbf{n}(\boldsymbol{\%})$ \\
\hline $\begin{array}{l}\text { Jenis Kelamin(n= 23) } \\
\text { Laki-laki }\end{array}$ & \\
$\quad$ Perempuan & $8(34,8)$ \\
\hline Usia(n=23) & $15(65,2)$ \\
$26-35$ tahun & $10(43,5)$ \\
36 - 45 tahun & $7(30,4)$ \\
$46-55$ tahun & $6(26,1)$ \\
\hline
\end{tabular}

\section{Pengalaman menangani} permasalahan menyusui $(\mathbf{n}=\mathbf{2 3})$

Sering

Kadang-kadang

$2(8,7)$

Tidak pernah

\begin{tabular}{lrr}
\hline $\begin{array}{l}\text { Pengalaman } \\
\text { pelatihan }\end{array}$ & $\begin{array}{r}\text { mengikuti } \\
\text { pendidikan }\end{array}$ & atau \\
laktasi & $19(82,6)$ \\
n=23) & & $3(13,0)$
\end{tabular}

Tidak pernah

Pernah 1 kali

Pernah 2 kali

Pernah 3 kali atau lebih

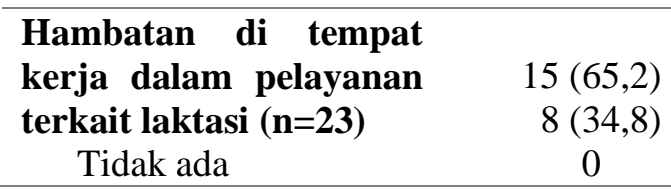




\begin{tabular}{lc}
\hline Fasilitas & 0 \\
Rekan kerja & \\
Atasan & \\
\hline Total & $\mathbf{2 3 ~ ( 1 0 0 )}$ \\
\hline
\end{tabular}

Tabel 1 menunjukkan karakteristik responden, pada penelitian ini terdiri dari 15 perempuan $(65,2 \%)$ dan 8 laki-laki $(34,8 \%)$ dengan rentang usia terbanyak yaitu antara 26-35 tahun (43,5\%). Dari 23 responden, 19 diantaranya $(82,6 \%)$ tidak pernah mengikuti pelatihan atau pendidikan terkait laktasi dan mayoritas responden menangani kasus permasalahan menyusui dengan intensitas kadang-kadang $(87,0 \%)$. Fasilitas menjadi faktor penghambat utama dalam memberikan pelayanan terbaik terkait laktasi yaitu sebesar $34,8 \%$.

Dari 5 karakteristik responden diatas, dihubungkan dengan tingkat pengetahuan awal dokter umum terkait permasalahan menyusui yang diperoleh dari hasil pre-test. (Tabel 2)

Tabel 2. Deskripsi tingkat pengetahuan awal (pretest) berdasarkan karakteristik responden $(n=23)$

\begin{tabular}{lc}
\hline Karakteristik & Mean \\
& (SD) \\
\hline $\begin{array}{l}\text { Jenis Kelamin } \\
\text { Laki-laki } \\
\text { Perempuan }\end{array}$ & \\
& $48,13 \quad(9,98)$ \\
& 50, \\
& $33,54)$ \\
\hline Usia & 51,00 \\
26 - 35 tahun & $(7,38)$ \\
36 - 45 tahun & 53,57 \\
$46-55$ tahun & $(9,00)$ \\
& 42,50 \\
& $(10,84)$ \\
\hline $\begin{array}{l}\text { Pengalaman menangani } \\
\text { permasalahan } \\
\text { menyusui }\end{array}$ & \\
$\quad \begin{array}{l}\text { Sering } \\
\text { Kadang-kadang }\end{array}$ & 45 \\
$\quad$ Tidak pernah & $(-$ \\
\hline $\begin{array}{l}\text { Pengalaman mengikuti } \\
\text { pelatihan/pendidikan }\end{array}$ & $59,25(9,90)$ \\
\hline
\end{tabular}

\begin{tabular}{lc}
\hline laktasi & $50,53(7,43)$ \\
$\quad$ Tidak pernah & $40,00(17,32)$ \\
Pernah 1 kali & $60,00(-$ \\
Pernah 2 kali & \\
\hline $\begin{array}{l}\text { Hambatan di tempat } \\
\text { kerja dalam pelayanan } \\
\text { terkait laktasi } \\
\quad \text { Tidak ada }\end{array}$ & $49,00(7,37)$ \\
$\quad$ Fasilitas & 50,63 \\
\hline
\end{tabular}

Tabel 2 menunjukkan nilai rata-rata (mean) pengetahuan awal dokter umum terkait permasalahan menyusui berdasarkan karakteristik dari responden. Berdasarkan jenis kelamin, diperoleh bahwa perbedaan nilai rata-rata dokter umum laki-laki dan dokter umum perempuan tidak berbeda jauh yaitu hanya 2,2. Sedangkan dari karakteristik usia, dokter umum dengan usia 46-55 tahun memperoleh nilai pengetahuan awal yang rendah dibanding dengan dokter umum berusia kurang dari 46 tahun yang memperoleh nilai rata-rata berkisar antar 51,00 sampai 53,57.

Pada tabel 2 juga diperoleh data terkait hasil rata-rata pengetahuan awal dokter umum berdasarkan pengalaman menangani kasus menyusui dan pengalaman mengikuti pelatihan atau pendidikan laktasi. Dari pengalaman menangani kasus menyusui, dokter umum yang mayoritas mengaku menangani kasus menyusui dengan intensitas kadang-kadang (lihat Tabel 5.1) memperoleh nilai rata-rata 49,25. Selain itu, dokter umum yang sebagian besar juga tidak pernah mengikuti pelatihan atau pendidikan laktasi (lihat Tabel 5.1) memperoleh nilai rata-rata 50,53 .

Karakteristik responden yang terakhir dihubungkan dengan nilai rata-rata pengetahuan dokter umum terkait permasalahan menyusui adalah lingkungan. Lingkungan yang dimaksud disini yaitu lingkungan kerja dokter umum yaitu puskesmas. Dari 23 dokter umum, 15 diantaranya mengaku memiliki lingkungan kerja yang mendukung untuk memberikan pelayanan terbaik terkait laktasi dan 8 yang lain mengaku fasilitas menjadi hambatan dalam memberikan pelayan terbaik. Dari tabel 5.2 menunjukkan rata-rata nilai dokter umum yang mengaku lingkungan kerjanya mendukung dan tidak mendukung memiliki perbedaan yang tipis yaituhanya sebesar 1,63 . 
Sedangkan Tabel 3 Menunjukan rata-rata nilai pengetahuan dokter umum terkait permasalahan menyusui sebelum dan setelah pemberian e-booklet, serta rata-rata perubahan nilai yang diperoleh oleh 23 dokter umum.

Tabel 3. Deskripsi Data Pretest, Posttest, \begin{tabular}{c|c|c|c|c|c}
\multicolumn{7}{c}{ dan Perubahan Nilai } \\
& $\begin{array}{l}\text { Jumlah } \\
\text { sampel } \\
\text { (N) }\end{array}$ & $\begin{array}{l}\text { Nilai } \\
\text { Minimum }\end{array}$ & $\begin{array}{l}\text { Nilai } \\
\text { Maksimum }\end{array}$ & $\begin{array}{l}\text { Rata-Rata } \\
\text { (Mean) }\end{array}$ & $\begin{array}{l}\text { Standart } \\
\text { Deviasi }\end{array}$ \\
\hline Pre-Test & 23 & 30 & 70 & 49,56 & 9,52 \\
Post-Test & 23 & 60 & 95 & 76,74 & 8,61 \\
$\begin{array}{c}\text { Perubahan } \\
\text { Nilai }\end{array}$ & 23 & 10 & 50 & 27,17 & 10,42
\end{tabular}

Berdasarkan tabel diatas ,terangkum nilai rata-rata pengetahuan awal (pretest), nilai rata-rata pengetahuan akhir (posttest), dan rata-rata perubahan nilai setelah diberi perlakuan. Diperoleh hasil bahwa terdapat peningkatan nilai rata-rata dokter umum terkait permasalahan menyusui setelah diberi perlakuan berupa e-booklet dengan rata-rata perubahan nilai sebesar 27,17. nilai tertinggi yaitu sebesar 32,50. Rata-rata perubahan nilai tersebut relatif jauh dengan dokter umum yang berusia 26-45 tahun yang hanya memperoleh rata-rata perubahan nilai $23,57-26,50$.

Oleh karena data penelitian ini berdistribusi normal, maka pengujian hipotesis dapat menggunakan metode parametrik yaitu Paired Sample $t$ Test. Pada tabel 6 menunjukkan hasil analisis diperoleh nilai $t_{\text {hitung }}$ sebesar $-12,500$ dengan nilai signifikansi sebesar 0,000 . Nilai $t_{\text {tabel }}$ pada derajat bebas 22 dan taraf nyata 0,05 sebesar 2,074. Apabila dilakukan pembandingan maka $\left|t_{\text {hitung }}\right|>t_{\text {tabel }}$ atau nilai signifikansi < 0,05 sehingga disimpulkan bahwa terdapat perbedaan rata-rata antara sebelum dan sesudah pemberian perlakuan. Karena ratarata posttest lebih tinggi daripada pretest, maka dapat dikatakan bahwa pemberian perlakuan berupa media pembelajaran (ebooklet) mampu meningkatkan nilai pengetahuan. Dengan kata lain, e-booklet efektif dalam meningkatkan pengetahuan dokter umum di puskesmas Kota Malang.

Tabel 6. Hasil Uji Hipotesis (Paired Sample t Test)

\begin{tabular}{|c|c|c|c|c|c|c|c|c|c|c|}
\hline Tabel & Distribusi & Perubaha & Nilai & & $\mathbf{N}$ & Mean & t hitung & db & Sig. & Keterangan \\
\hline & berdasarkan & Jenis & kelamin & Pretest & 23 & $\begin{array}{l}49,56 \\
7674\end{array}$ & $-12,500$ & 22 & 0,000 & $\begin{array}{c}\text { Berbeda } \\
\text { sionifikan }\end{array}$ \\
\hline
\end{tabular}

$\begin{array}{lll}\begin{array}{l}\text { Karakterstik } \\ \text { Responden }\end{array} & \begin{array}{l}\text { Rata-rata } \\ \text { perubahan nilai }\end{array} & \text { PEMBAHASAN }\end{array}$
(SD)

\begin{tabular}{ll}
\hline $\begin{array}{l}\text { Jenis Kelamin } \\
\text { Laki-laki }\end{array}$ & $26,88 \quad(9,61)$ \\
Perempuan & $27,33 \quad(11,16)$ \\
\hline Usia & \\
$26-35$ tahun & $26,50(12,03)$ \\
$36-45$ tahun & $23,57(8,52)$ \\
$46-55$ tahun & $32,50(8,80)$ \\
\hline
\end{tabular}

Peningkatan pengetahuan yang dilihat berdasarkan perubahan nilai merupakan tujuan utama dari penelitian ini. Pada tabel 5.4 ditunjukkan besarnya perubahan nilai setelah pemberian media pembelajaran berdasarkan jenis kelamin dan usia. Berdasarkan jenis kelamin, rata-rata perubahan nilai antara laki-laki dan perempuan tidak berbeda jauh yaitu hanya berselisih 0,45 . Sedangkan berdasarkan usia, dokter umum dengan rentang usia 46-55 tahun justru mendapatkan rata-rata perubahan

\section{Praktik Pemberian ASI Eksklusif}

Menurut Notoatmodjo S , pengetahuan adalah hasil tahu kepada suatu obyek yang diperoleh melalui penginderaan. Dengan sebuah pengetahuan memungkinkan seseorang untuk memecahkan masalah yang dihadapi ${ }^{8}$. Pengetahuan dokter umum tentang permasalahan menyusui diartikan sebagai kesan dan pemahaman yang dimiliki oleh dokter umum setelah melakukan pengindraan terkait dengan permasalahan menyusui.

Hasil analisis diketahui tingkat pengetahuan awal dokter umum tentang permasalahan menyusui relatif rendah yaitu dengan rata-rata nilai 49,56. Hasil ini dapat diartikan bahwa dokter umum di puskesmas Kota Malang kurang memahami dan menguasai dengan baik terkait permasalahan menyusui. Ditunjukkan dengan kemampuan 
dokter umum menjawab pertanyaan tentang permasalahan menyusui.

Pengetahuan memiliki peran penting untuk membentuk prilaku dan kepercayaan diri dokter umum. Pengetahuan, prilaku, dan kepercayaaan diri dokter umum tentang permasalahan menyusui akan menjadi bekal yang baik bagi dokter umum untuk menangani kasus-kasus permasalahan menyusui. Pengetahuan dokter umum dapat dipengaruhi oleh beberapa faktor. Pada penelitian ini peneliti menghubungkan karakteristik responden yaitu jenis kelamin, usia, pendidikan, pengalaman, dan lingkungan dengan tingkat pengetahuan awal dokter umum terkait permasalahan menyusui.

Dari 23 responden dokter umum yang diperoleh dari seluruh puskesmas Kota Malang, didapatkan responden dengan rincian 15 perempuan $(65,25)$ dan 8 laki-laki $(34,8 \%)$. Hasil analisis statistik menunjukkan rata-rata nilai pengetahuan dokter umum perempuan sebesar 50,33 sedangkan dokter umum laki-laki sebesar 48,13. Hal tersebut menunjukkan tingkat pengetahuan dokter umum perempuan dan laki-laki hanya berbeda 2,2. Hasil tersebut bisa disimpulkan bahwa jenis kelamin tidak mempengaruhi tingkat pengetahuan dokter umum terkait permasalahan menyusui. Kesimpulan tersebut sesuai dengan yang dikemukakan Fuadbahsin bahwa apapun jenis kelamin seseorang, bila dia masih produktif, berpendidikan, atau berpengalaman maka ia akan cenderung mempunyai tingkat pengetahuan yang tinggi ${ }^{9}$.

Berdasarkan hasil penelitian diketahui karakteristik responden usia menunjukan terdapat 10 dokter umum $(43,5 \%)$ pada rentang usia 26-35 tahun, 7 dokter umum $(30,4 \%)$ pada rentang usia 36-45, dan 6 dokter umum $(26,1 \%)$ berusia $46-55$ tahun. Berkaitan dengan pengetahuan terkait permasalahan menyusui, dokter umum pada rentang usia 46-55 tahun mempunyai pengetahuan yang paling rendah dengan ratarata nilai sebesar 42,50 berbeda jauh dengan dokter umum dengan rentang usia 26-45 tahun yaitu memperoleh rata-rata berkisar 51,00 sampai 53,57. Hal ini didukung dengan pernyataan Abu Ahmadi, bahwa daya ingat seseorang itu salah satunya dipengaruhi oleh usia. Dengan bertambahnya usia seseorang dapat berpengaruh pada pertambahan pengetahuan yang diperolehnya, akan tetapi pada usia-usia tertentu atau menjelang usia lanjut kemampuan penerimaan atau mengingat suatu pengetahuan akan berkurang $^{10}$.

Pendidikan juga mempengaruhi pengetahuan dokter umum. Sebagai dokter umum tentunya telah melewati tahap pendidikan sarjana kedokteran dan tahap profesi dokter. Yang dapat membedakan antar dokter yaitu pendidikan non formal atau pelatihan-pelatihan terutama terkait laktasi. Hasil analisis karakteristik responden penelitian diketahui 19 dari 23 responden tidak pernah mengikuti pendidikan atau pelatihan terkait laktasi dengan nilai rata-rata pengetahuan sebesar 50,53 yang tergolong rendah. Padahal, menurut Ratna Wati pengalaman belajar akan menghasilkan pengembangan pengetahuan dan keterampilan serta dapat mengembangkan kemampuan dalam mengambil keputusan ${ }^{11}$.

Lingkungan juga menjadi faktor yang dapat mempengaruhi pengetahuan dokter umum terkait permasalahan menyusui. Lingkungan yang dimaksud disini yaitu lingkungan tempat kerja dalam hal ini puskesmas. Berdasarkan hasil penelitian diketahui 15 dokter umum yang mengaku lingkungan memberi dukungan untuk memberikan pelayanan terbaik terkait laktasi memperoleh nilai pengetahuan rata-rata sebesar 49,00 dan 8 dokter umum yang mengaku fasilitas merupakan penghambat untuk memberikan pelayanan terbaik terkait laktasi memperoleh nilai rata-rata 50,63. Perbedaan yang sangat tipis menjelaskan bahwa faktor lingkungan tempat kerja tidak terlalu mempengaruhi kepada pengetahuan dokter umum terkait permasalahan menyusui. Hasil tersebut tidak sesuai dengan teori dari Notoatmodjo yang mengungkapkan bahwa fasilitas merupakan sumber informasi yang menjadi salah satu faktor yang dapat mempengaruhi pengetahuan seseorang ${ }^{8}$. Ketidaksesuain tersebut dapat disebabkan karena faktor lingkungan tempat kerja hanya satu dari sekian banyak faktor yang dapat mempengaruhi pengetahuan dokter umum yang bekerja di puskesmas.

\section{Efektifitas e-booklet terhadap Peningkatan Pengetahuan Dokter Umum terkait Permasalahan Menyusui}

Peningkatan pengetahuan responden mencerminkan peningkatan pengetahuan 
yang dipengaruhi oleh adanya bantuan media pembelajaran yang lebih memudahkan responden dalam mengingat materi yang diberikan. Penelitian Nurhidayat yang meneliti mengenai peningkatan pengetahuan siswa tentang kesehatan gigi dan mulut dengan menggunakan media menyimpulkan bahwa sangat diperlukan media sebagai alat bantu dalam meningkatkan kemampuan mengingat seperti gambar dan suara sehingga cepat memahami dari informasi yang diberikan dari media flip Chart maupun dalam bentuk power point ${ }^{12}$.

Dalam penelitian ini, Digunakan $e$ booklet sebagai media pembelajaran. Ebooklet merupakan alat bantu berbentuk buku elektronik yang dapat disimpan di smarthphone, Personal Computer (PC), maupun laptop yang dilengkapi dengan tulisan maupun gambar yang disesuaikan dengan sasaran pembacanya. Informasi yang ada dalam e-booklet disusun dengan jelas dan rinci sehingga dapat ditangkap dengan baik oleh sasaran pendidikan dan tidak menimbulkan kesalahan persepsi. Penggunaan media e-booklet sebagai media pembelajaran kepada dokter umum, akan membuat sasaran lebih mudah memahami informasi yang disampaikan dibandingkan penyampaian informasi hanya secara lisan, karena sasaran pendidikan dapat mengamati langsung gambar dan tulisan yang merupakan penjelasan terhadap gambar yang ada dalam media tersebut. Isi informasi e-booklet pada penelitian ini merupakan gabungan dari gambar-gambar yang menarik serta kalimat yang mudah dipahami, sehingga akan lebih memudahkan dalam menangkap materi permasalahan menyusui yang disampaikan. Gambar yang menarik dalam e-booklet akan semakin menarik minat untuk membaca dan fokus pada informasi yang disampaikan karena tidak cepat bosan.

Keunggulan dalam menggunakan media booklet antara lain dapat mencakup banyak orang, praktis dalam penggunaannya karena dapat dipakai di mana saja dan kapan saja, dan karena booklet tidak hanya berisi teks tetapi terdapat gambar sehingga dapat menimbulkan rasa keindahan serta meningkatkan pemahaman dan gairah dalam belajar $^{13}$. Selain itu, penggunaan media elektronik dalam media pembelajaran perlu dikembangkan. Dengan media pembelajaran elektronik objek-objek yang ingin diperlihatkan dapat ditampilkan dalam warna yang lebih realistik dan orisinil. Di samping itu, perangkat slide ini mudah disusun kembali bila perlu, dapat dikombinasikan dengan alat lain agar lebih efektif, dan dapat disesuaikan dengan kepentingan setiap individu atau kelompok.

Berdasarkan hasil uji $t$ berpasangan (Paired Sample t Test) didapatkan |thitung| > ttabel atau nilai signifikansi $<0,05$. Hasil tersebut menunjukkan terdapat perbedaan rata-rata antara sebelum dan sesudah pemberian perlakuan. Maka, dapat disimpulkan bahwa pemberian perlakuan berupa media pembelajaran (e-booklet) mampu meningkatkan nilai sampel. Dengan kata lain, e-booklet efektif dalam meningkatkan pengetahuan.

Penelitian ini sejalan dengan penelitian Diyah Sariyansah, yaitu booklet efektif terhadap peningkatan pengetahuan tentang alat pelindung diri di pabrik tahu desa Kalibening Banjarnegara ${ }^{14}$. Hasil penelitian ini juga diperkuat dengan hasil penelitian dari Indah Yulianti yang menyatakan bahwa dengan menggunakan media booklet lebih baik dalam meningkatkan pengetahuan terhadap responden tentang Pemberantasan Sarang Nyamuk (PSN) Demam Berdarah Dengue (DBD) di Desa Plumbungan Kecamatan Karang Malang Kabupaten Sragen ${ }^{15}$. Sebagai pembanding dengan media pembelajaran lain, ditemukan pada penelitian Diah Ratna Fitriastutik bahwa Media booklet lebih efektif dalam meningkatkan pengetahuan tentang karies gigi daripada permainan tebak gambar dan ceramah pada siswa kelas IV sekolah dasar ${ }^{16}$.

Keefektifan penggunaan media pembelajaran juga dapat dipengaruhi oleholeh karakteristik dari responden diantaranya adalah jenis kelamin. Perbedaan perempuan dan laki-laki hampir terjadi dalam berbagai bidang, yaitu bidang pendidikan, pekerjaan, politik dan sebagainya. laki-laki dan perempuan memiliki karakteristik yang berbeda, baik secara fisiologis yaitu kondisi fisik, panca indera, dan sebagainya maupun psikologis yang menyangkut minta, tingkat kecerdasan, bakat, motivasi, dan kemampuan kognitifnya. Hal tersebut dapat mempengaruhi bagaimana proses dan hasil belajarnya ${ }^{17}$.

Dari hasil analisis hubungan antara perubahan nilai berdasarkan jenis kelamin 
didapatkan, dokter umum perempuan memiliki rata-rata peningkatan nilai lebih besar yaitu 27,33 berbanding 26,88 untuk dokter laki-laki. Namun, dilihat dari perbedaan yang hanya 0,45 , dapat disimpulkan tidak ada pengaruh signifikan antara jenis kelamin dengan perubahan nilai. Hasil sesuai dengan yang dikemukakan Gallangher yang dikutip oleh Sugihartono yaitu meskipuan laki-laki dan perempuan memiliki perbedaan dalam perkembangan fisik, emosional, dan intelektual.. Prestasi akademik tidak dapat dijelaskan melalui perbedaan biologis ${ }^{18}$. Faktor sosial dan kultural merupakan alasan utama yang menyebabkan terdapat perbedaan gender dalam prestasi akademik. Hal ini sejalan dengan penelitian Rohmah Dwi Yuniarti bahwa gender tidak memberikan pengaruh yang sangat signifikan terhadap prestasi belajar bahasa Indonesia ${ }^{19}$.

Karakteristik yang juga memungkin untuk mempengaruhi keefektifan penggunaan media pembelajaran adalah usia responden. Diperoleh hasil dokter umum dengan rentang usia 46-55 tahun mendapatkan rata-rata perubahan nilai tertinggi yaitu sebesar 32,50. Rata-rata perubahan nilai tersebut relatif jauh dengan dokter umum yang berusia 26-45 tahun yang hanya memperoleh rata-rata perubahan nilai 23,57-26,50. Hasil tersebut tidak sejalan dengan pendapat Notoatmodjo yang mengemukakan Intelligence Quotient (IQ) seseorang akan menurun cukup cepat sejalan dengan bertambahnya usia yang akan mempengaruhi daya tangkap dan pola pikir . Namun, hasil tersebut dapat disebabkan karena adanya motivasi untuk mempelajari $e$ booklet yang diberikan. Adanya motivasi dapat timbul karena dokter umum yang berusia 46-55 tahun mengalami kesulitan saat mengerjakan soal pretest. Sesuai pendapat Sardiman bahwa Motivasi Belajar merupakan faktor penggerak yang berasal dari dalam diri individu untuk menumbuhkan gairah, merasa senang dan semangat untuk belajar ${ }^{20}$. Hal ini sejalan dengan penelitian Muhammad Ilyas yaitu terdapat pengaruh positif dan signifikan motivasi belajar terhadap prestasi belajar akuntansi ${ }^{21}$.

\section{KETERBATASAN PENELITIAN}

Pada penelitian ini memiliki beberapa keterbatasan. Keterbatasan ini adalah:
1. Pada penelitian ini peneliti tidak dapat memastikan bahwa dokter umum benarbenar mempelajari e-booklet tersebut atau tidak. Hal ini dikarenakan peneliti memberikan waktu selama 2 minggu kepada dokter umum untuk mempelajarinya dan selama itu pula peneliti hanya bisa mengingatkan melalui pesan pendek.

2. Keterbatasan waktu untuk bertemu dengan responden dikarenakan tidak diizinkannya menemui dokter umum pada saat jam pelayanan. Oleh karena itu peneliti hanya bisa menemui dokter umum pada pagi hari sebelum pelayanan atau siang hari setelah pelayanan.

3. Masih kurangnya penelitian kepada dokter umum dan pembahasan terkait dokter umum menjadi keterbatasan referensi bagi peneliti.

4. Masih kurangnya penelitian menggunakan elektronik booklet menjadi keterbatasan referensi bagi peneliti.

\section{KESIMPULAN}

Berdasarkan anali sadata dan pembahasan, pada penelitian ini dapat disimpulkan bahwa

1. Pemberian media pembelajaran berupa $e$ booklet efektif untuk meningkatkan pengetahuan terkait permasalahan menyusui dokter umum di puskesmas Kota Malang.

2. Pengetahuan awal dokter umum terkait permasalahan menyusui di puskesmas Kota Malang ternilai kurang.

3. Pengetahuan dokter umum terkait permasalahan menyusui di puskesmas Kota Malang setelah diberikan media pembelajaran e-booklet ternilai cukup.

\section{SARAN}

Guna pengembangan lebih lanjut maka peneliti menyarankan:

1. Perlu dilakukan penelitian dengan media pembelajaran lain kepada dokter umum untuk mengetahui tingkat keefektifan media pembelajaran. 
2. Pada penelitian selanjutnya sebaiknya harus mengambil sampel lebih banyak dengan cara memilih sampel tidak hanya terbatas pada dokter umum di puskesmas melainkan dokter umum di rumah sakit, klinik, maupun praktik mandiri.

3. Perlu dipertahankan dan ditingkatkan program pendidikan dan pelatihan kepada dokter umum berkaitan laktasi sehingga dapat meningkatkan pengetahuan dokter umum.

\section{UCAPAN TERIMAKASIH}

Peneliti mengucapkan terimakasih kepada responden yang turut berpartisipasi dan para dosen pembimbing serta staf FK UNISMA yang telah membantu dan memberi dukungan terhadap penelitian ini.

\section{DAFTAR PUSTAKA}

1. WHO. Exclusife Breastfeeding. http://www.who.int/maternal child a dolescent/topics/newborn/nutrition/br eastfeeding/en/ [online : diakses 20 Desember 2016]

2. Roesli. Mengenal ASI Eksklusif .Jakarta : Pustaka Pengembangan Swadaya Nusantara. 2000

3. Suradi. Manajemen Laktasi. Jakarta: Perkumpulan Perinatologi Indonesia. 2004

4. Konsil Kodokteran Indonesia. Standar Kompetensi Dokter Indonesia 2012. Jakarta , 2012

5. Dinas Kesehatan Provinsi Jawa Timur. . Profil Kesehatan Provinsi Jawa Timur Tahun 2013. Surabaya : Depkes Jawa Timur, 2014

6. Arsyad, A. Media Pembelajaran. Jakarta : Penerbit PT. Rajagrafindo Persada . 2006

7. Mintarsih. Pendidikan Kesehatan Menggunakan Booklet dan Poster Dalam Meningkatkan Pengetahuan dan Sikap Remaja Tentang Kesehatan Reproduksi di Kabupaten Tasikmalaya. Tesis. Universitas Gadjah Mada, 2007.

8. Notoatmodjo, S. Promosi Kesehatan dan Ilmu Perilaku. Jakarta : Rineka Cipta , 2007

9. Fuadbahsin. 2009. Tinjauan uтum pengetahuan. [online] Diakses dari http://clickgtg.com/2008/12/kniwled ge-apa-ukurannya.htm tanggal 16 Juni 2017.

10. Abu, Ahmadi. 2011. Pengertian Prestasi Belajar (online). http://belajarpsikologi.com/pengertia n-prestasi-belajar/, diakses pada tanggal 16 Juni 2017

11. Ratnawati.. Penelitian Tindakan Dalam Bidang Pendidikan dan Sosial. Mojokerto : Bayu Media Publishing, 2009

12. Nurhidayat. Perbandingan Media Power Point dengan Flip Chart dalam Meningkatkan Pengetahuankesehatan gigi dan mulut. Unnes Journal of Public Healthhttp://journal.unnes.ac.id /sju/index.php/ujph , 2012

13. Notoatmodjo, S. Metodologi Penelitian Kesehatan. Jakarta : Rineka Cipta, 2005

14. Diyah sariyansah. Keefektifan Booklet Terhadap Pengetahuan Tentang Alat Pelindung Diri Pada Pekerja Pabrik Tahu Desa Kalibening Banjarnegara. univeristas negeri semarang. Skripsi. 2014

15. Yulianti, indah. Booklet untuk meningkatkan pengetahuan pemberantasan sarang nyamuk (Psn) Demam Berdarah Dengue (DBD) di desa plumbungan kecamatan karang Jurnal Keperawatan Vol.2(2), 2013

16. Diah Ratna Fitriastutik . Efektivitas Booklet Dan Permainan Tebak Gambar Dalam Meningkatkan Pengetahuan Dan Sikap Siswa Kelas Iv Terhadap Karies Gigi Di Sd Negeri 01, 02, Dan 03 Bandengan Kecamatan Jepara Kabupaten Jepara Tahun Ajaran 2009/2010. Skripsi.Universitas Negeri semarang, 2010

17. Utami, Sri Marlia . Pengaruh gaya belajar berdasarkan gender terhadap kemampuan kritis siswa kelas XI pada konsep sistem pernapasan manusia. Universitas Indonesia, 2013

18. Sugihartono, dkk . Psikologi Pendidikan, Yogyakarta. UNY Press, 2007

19. Rohmah Dwi Yuniarti. Pengaruh Sikap Dan Gender Terhadap Prestasi Belajar Bahasa Indonesia 
Pada Siswa Smp Negeri Kelas Vii Di

Kecamatan Sleman Yogyakarta 2013/2014 .skripsi. Universitas Negeri Yogyakarta , 2014

20. Sardirman . Interaksi dan Motivasi belajar mengajar. Jakarta. PT Rajawali pers, 2009

21. Muhammad Ilyas. Pengaruh Motivasi Belajar Dan Lingkungan Belajar Terhadap Prestasi Belajar Akuntansi Siswa Kelas Xi Ips Sma Negeri 1 Ngaglik Tahun Ajaran 2013/2014. Skripsi. Univeristas Negeri Yogyakarta, 2014 